\title{
LEGISLATION ON THE PROTECTION \\ OF AGRICULTURAL LAND \\ IN THE CONTEXT OF THE IMPLEMENTATION OF \\ THE THEMATIC STRATEGY FOR SOIL PROTECTION \\ IN SLOVAK CONDITIONS
}

\author{
PRÁVNA ÚPRAVA \\ OCHRANY POLNOHOSPODÁRSKEJ PÔDY \\ V KONTEXTE IMPLEMENTÁCIE TEMATICKEJ \\ STRATÉGIE NA OCHRANU PÔDY \\ V PODMIENKACH SLOVENSKA
}

Lucia PALŠOVÁ*

\section{Introduction}

Contemporary Slovak society draws its attention to quality of life and healthy lifestyle, especially in the field of food safety, water quality, pleasant landscape, preservation of cultural and natural heritage and so on. Soil as a natural component has an irreplaceable role in each of these activities. As stated at http://ec.europa.eu/environment/soil/three_en.htm, soil is extremely complex and changeable environment. There

\section{Abstract (EN)}

Protecting the qualitative aspect of the agricultural land is in the interest of European Union policies and Slovakia as well. The EU adopted in 2006 a Thematic Strategy for Soil Protection to ensure protection and sustainable use of land, including agricultural land. The aim of this paper is to analyze and evaluate legislation protecting agricultural land in the context of the implementation of the Thematic Strategy for Soil Protection in Slovakia. The basic legislation for the protection of agricultural land in Slovakia is the Act No. 220/2004 Coll. on the conservation and use of agricultural land and amending Act No. 245/2003 Coll. concerning integrated pollution prevention and control and amending certain laws, as amended, which provides a basic framework for conservation of the agricultural land. In terms of preserving, agricultural land has significant importance in the Common Agricultural Policy pillar I and II which stipulate cross-compliance requirements, requirements for agri-environmental measures for applicants for single area payment scheme, for applicants for support under agri-environmental measures respectively.

\section{Keywords (EN)}

agricultural Land, Land Protection, the Thematic Strategy for Soil Protection, the Proposal for a Framework Directive for the Protection of Soil, Legal Acts are more than 320 main soil types identified in Europe and each of them differs from one another physically, chemically and biologically. Soil structure plays a determining role in terms of its ability to perform its functions. Any damage to soil structure leads to damaging the environment and other ecosystems. A number of studies aimed at detecting soil quality in Europe pointed out the deteriorating state of this area. The European Union responded to the findings with

\section{Abstrakt (SK)}

Ochrana kvalitatívnej stránky polnohospodárskej pôdy je v záujme politiky Európskej únie ako aj Slovenska. EÚ prijala v roku 2006 tematickú stratégiu na ochranu pôdy, ktorej cielom je ochrana a trvalo udržatel'né využívanie pôdy, vrátane polnohospodárskej pôdy. Cielom príspevku je $\mathrm{v}$ tejto súvislosti analyzovat’ a zhodnotit’ právnu úpravu ochrany polnohospodárskej pôdy v kontexte implementácie tematickej stratégie na ochranu pôdy v podmienkach Slovenska. Základným právnym predpisom na ochranu polnohospodárskej pôdy na Slovensku je z.č. 220/2004 Z.z. 0 ochrane a využívaní polnohospodárskej pôdy a o zmene zákona č. 245/2003 Z.z. 0 integrovanej prevencii a kontrole znečistovania životného prostredia a 0 zmene a doplnení niektorých zákonov v znení neskorších predpisov, ktorý poskytuje základný rámec starostlivosti o ochranu pol'nohospodárskej pôdy. Z hladiska zachovania dobrého stavu pol'nohospodárskej pôdy má však markantný význam Spoločná polnnohospodárska politika- I. a Il. pilier, ktorý stanovuje pre žiadatel'ov jednotnej platby na plochu, resp. žiadatelov podpory v rámci agroenvironmentálnych opatrení, požiadavky na krĩzové plnenie a resp. požiadavky na agroenvironmentálne opatrenia.

\section{Kl'účové slová (SK)}

pol'nohospodárska pôda, ochrana pôdy, Tematická stratégia na ochranu pôdy, návrh rámcovej smernice pre ochranu pôdy, právne predpisy

Slovak University of Agriculture in Nitra 
the adoption of a Thematic Strategy for Soil Protection. The strategy consists of a Communication from the Commission to other European institutions COM (2006) 231 final, a Proposal for a Framework Directive COM (2006) 232 final and an Impact Assessment SEC (2006) 620 and SEC (2006) 1165. Although the strategy is not legally enforceable, the EU Member States are obliged to facilitate the implementation of the intentions of the strategy. In Slovakia, soil protection is implemented mainly by legislative and economic instruments, which, however, do not have a unitary character for all of the soil types, but the legislation is fragmented to various regulations according to the type of the regulated area (e.g., water, agricultural land, etc.).

\section{Material and Methods}

Soil protection includes extensive legislation depending on the soil type. As the agricultural land represents one of the most vulnerable soil types and is burdened by production activities and at the same time stands for the basis of the food security, the aim of this paper is to analyze and evaluate the legislation on the protection of agricultural land in the context of the implementation of the Thematic Strategy for Soil Protection COM (2006) 231 final in Slovak conditions. Results of the paper are based on the research task of the project Jean Monnet Centre of Excellence "EU land policy - the pathway towards suistainable Europe", 542600-LLP-1 -2013-1SK-AJM-PO, Decision No. 2013-2883/001-001.

The basis for the elaboration of the paper was provided by secondary information sources, particularly legal acts of the European Union, Slovak legislation and statistical data relating to agricultural land in Slovakia and in the EU. The methodological apparatus involves methods of selection, analysis, induction, deduction and scientific abstraction.

\section{Results and Discussion}

In terms of the soil protection, agricultural land represents one of the most important areas, because it is this soil type that is influenced by the current mainly conventional agricultural production, which burdens this natural resource unbearably. Soil degradation is one of the biggest and persistent problems of the EU. European Union responded to the situation with the adoption of the Thematic strategy for Soil Protection ${ }^{(1)}$ consisting of the Communication from the Commission to other European institutions COM (2006) 231 final, from the Proposal for the Framework Directive COM (2006) 232 final and the Impact Assessment SEC (2006) 620 and SEC (2006) 1165.

The reason for issuing the Thematic Strategy was the fact that the state of the soil in Europe is worsening and soil protection policy in the EU is not coherent; measures adopted for soil protection are fragmented to many areas aimed at

(1) Thematic strategy for soil protection was preceded by issuing the communication from the Commission to the Council, the European Parliament, the European Economic and Social Committee and the Committee of the Regions: Towards a thematic strategy for soil protection COM (2002) 179 final. protection of other components of the environment. The general objective of the strategy is to protect sustainable soil use and the Strategy is based on the following principles:

1. to prevent further soil degradation and to protect functions of soil:

- as long as the soil and its functions are used, measures related to soil use methods and management methods must be adopted;

- if the soil serves as an absorber/receptor of the effects of human activities or environmental phenomena, the measures must be adopted directly at source.

2. to restore the soil affected by degradation to the level of functionality that would be compatible with the current and planned use at least, and thereby to take into account the cost invested into the soil restoration.

To achieve those objectives, the EU appeals for the implementation of the activities on several levels while preserving the principles of subsidiarity and proportionality. The Strategy is based on four fundamental pillars:

1. framework legislation;

2. integration - inclusion of soil protection into policies elaborated and implemented on both domestic and EU levels;

3. filling the known gaps in knowledge in some areas of soil protection through the research supported by the EU;

4. raising public awareness of the need for soil protection.

As the evaluation review of the Thematic Strategy for Soil Protection, the European Commission issued a report to the European Parliament, the Council, the European Economic and Social Committee and the Committee of the Regions COM (2012) final named Implementation of the Thematic Strategy for Soil Protection and ongoing activities. The Communication points out the overview of the implementation of the four pillars of the Thematic Strategy for Soil Protection from 2006-2012 and refers to the current tendencies in soil degradation in Europe and on the global level and to future challenges related to ensuring the protection as well.

\section{Pillar I - Framework Directive}

Although the very report does not reflect the evolution of the framework legislation, a Proposal for a Framework Directive for the Protection of Soil was elaborated in 2006 and was published as a Proposal for a Directive of the European Parliament and the Council laying down the framework for the soil protection and amending Directive 2004/35/EC COM (2006) 232 final. Art. 1 of the Directive amends its material scope, which represents the provision of the framework for the soil protection and the preservation of the ability of the soil to perform any of the following environmental, economic, social and cultural functions:

- biomass production, including the areas of agriculture and forestry as well;

- collection, filtration and transformation of nutrients, substances and water;

- the source of biological diversity, such as habitats, species and genes;

- physical and cultural environment for humans and hu- 
man activity;

- source of raw materials;

- carbon reservoir;

- archive of the geological and cultural heritage.

The directive also establishes the measures designated to prevent soil degradation processes, which occur either naturally or as a result of a wide range of human activities and disrupt the ability of the soil to perform the functions mentioned. Despite the fact that it establishes a framework for legislative adjustment in maintaining the principle of subsidiarity declared and while providing the EU Member States a great deal of flexibility in the implementation of the requirements, the Directive has not been adopted to the present date. Although the reasons for the blockage of the further procedure differ, the most common causes are violation of the subsidiarity principle by the adoption of the aforementioned directive $^{(2)}$, high costs of the implementation of the Directive, the administrative burdens and overlapping of the European directive with the national legislations of the Member States ${ }^{(3)}$. However, as stated by the current European Commissioner for the Environment Potočnik ${ }^{(4)}$, the Directive should lay down the inevitable legal framework for the soil protection at the European level ${ }^{(5)}$. As he notes after the seven years, during which the Proposal for the Directive has been deadlocked, it is necessary for the Proposal to be revised in terms of the commitments adopted in the $7^{\text {th }}$ Environment Action Programme $^{(6)}$ in the way allowing the Directive to be able to

(2) Germany and the Great Britain, for example, take the view that the EU does not have the competence to act in the area of soil protection. Rankin, J. in European Voice. 2010. Member states dig deep to stop soil directive. [cit. 2014-05-15]. Available at: http://www.europeanvoice.com/article/imported/memberstates-dig-deep-to-stop-soil-directive/67043.aspx

(3) Opponents of the adoption of the Directive assert that there is no need for further supplementary legislation in the area of the soil protection, because the soil issue is addressed by a number of legal acts across the European Union. (e.g., NATIONAL Farming Union. Faming Online. EU Soils Directive: Protection for Europe's degraded soils under threat. [cit. 2014-05-14]. Available at: http://www.farming.co.uk/news/article/8990

(4) Potočnik J. in EAOsite editor. 2014. Soil directive appears doomed. [cit. 2014-05-14]. Available at: http://eaonsite.com/index.php?option=com_k2\&view=item\& $r i d=16589$ : soil-directiveappears-doomed\&Itemid $=675$

(5) European Environment Agency is constantly pointing out the deteriorating situation in the area of the soil degradation, mainly in the areas such as the loss of soil permeability (as a result of a permanent coverage of the soil with impermeable material), soil erosion, soil compaction, contamination, acidification and salination of the soil. The deteriorating state of the agricultural land is caused mostly by inappropriate agricultural practices and tourism. http://www.eea.europa.eu/soer

(6) The $7^{\text {th }}$ Environment Action Programme subtitled "Living well, within the limits of our planet" is a part of a long-term vision and strategy of the EU's direction in the area of environment and climate protection until 2050. The EU aims for us to live in accordance with the ecological limits of the planet until 2050. The current $7^{\text {th }}$ Environment Action Programme covers the period of 2014-2020. The Programme includes nine priority objectives, including the improvement of the implementation of the EU legislation in the area of environment and the improvement of the interconnection of the environmental legislation with legislation ensure effective and targeted soil protection in the EU. As a Commissioner, he also stated that the adoption of the Directive had constantly been obstructed by the political unwillingness of the Member States: Germany (opposition leader), France, Great Britain, Austria and the Netherlands.

Pillar II Integration - Inclusion of Soil Protection into Policies Elaborated and Implemented on Both Domestic and EU Levels

From the perspective of the integration of the soil protection issues as a part of the environment into other policies, the connection with the Common Agricultural Policy was important. The introduction of cross-compliance in 2003 was a significant step in reducing erosion, maintaining and increasing the content of organic substances and preventing their compaction. In the programming period 2014-2020, the modification of the cross-compliance will be tightened, particularly in terms of the soil protection ${ }^{(7)}$. In addition to establishing the cross-compliance in the pillar I, Member States have been allowed to address agri-environmental measures under the framework of the Axis 2 of the Rural Development Programme. The aim of the measures mentioned above was to support the additional soil protection activities.

Among other things, the report claims that the soil protection had been integrated into other areas such as: industrial equipment, cohesion policy, state aid for the reclamation of the contaminated soil.

Pillar III Filling the Known Gaps in Knowledge in Some Areas of Soil Protection through the Research Supported by the EU

In terms of the third pillar, it was stated that awareness of the soil had improved in the EU, due to, among other things, the organization of public events devoted to soil protection, publication of soil atlases and support of numerous instruments and networks, including the European Network on Soil Awareness (ENSA).

Pillar IV Raising Public Awareness of the Need for Soil Protection

The $4^{\text {th }}$ pillar has been implemented by means of the research activities related to solving soil problems, particularly through the 7th Framework Programme for Research. ${ }^{(8)}$

\section{Thematic Strategy for Soil Protection in Slovak condi- tions}

As far as Slovakia is concerned, agricultural land represents $2,405,971$ ha $(49.01 \%)$ of the total amount of land in Slovakia (Geodesy, Cartography and Cadastre Authority of the Slovak Republic, 2014) and as defined within the meaning of Section 2 Point (b) of the Act No. 220/2004 Coll., on the

of other areas. Available at: http://ec.europa.eu/environment/ newprg/

(7) More information available at: http://ec.europa.eu/environment/soil/studyl_en.htm.

(8) Community Research and Development Information Service. Available at: http://cordis.europa.eu 
Fig. 1: Agricultural land types in Slovakia on 1.1.2014

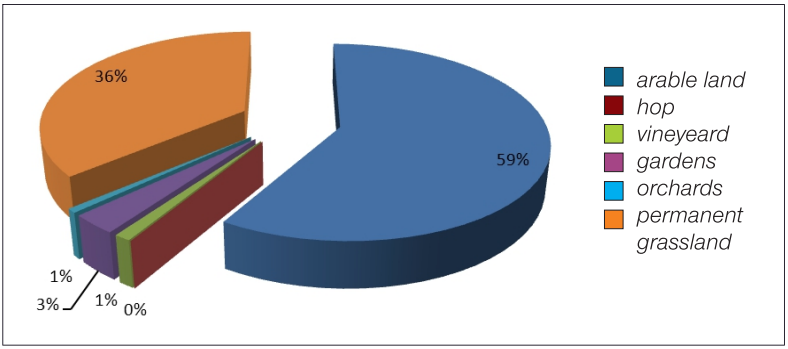

Source: Geodesy, Cartography and Cadastre Authority of the Slovak Republic (2014), Custom data processing

conservation and use of agricultural land and amending the Act No. 245/2003 Coll. on integrated pollution prevention and control and amending certain acts as amended, agricultural land stands for a production potential land, which is registered as arable land, hop gardens, vineyards, orchards, gardens and permanent grassland in the Cadastre.

The figure 1 leads us to a conclusion that the protection of the quality of agricultural land has its meaning, since only $1,413,129$ ha $(58.73 \%)$ from the total agricultural land can be used as an arable land, the rest of the agricultural land is represented by permanent grassland 868,061 ha (36.01\%), a smaller amount of the land includes gardens 76,447 ha (3.19\%), vineyards 26,750 ha (1.11\%), orchards 16,793 ha $(0.7 \%)$ and the smallest part is represented by the hop gardens $513(0.02 \%)$ of the total agricultural land area. In general, however, it can be stated that the agricultural and arable lands area decreases in favour of forest, non-agricultural and non-forest lands.

Part I Legislation on the Protection of Agricultural Land In spite of the data mentioned above, the very agricultural land area is not meaningful in relation to the quality of agricultural land. As asserted by the European Union, Slovakia also records soil degradation, contamination, erosion and compaction as results of the conventional land use utilizing heavy agricultural machinery, which is used in rather large areas of agricultural land. Legislation on the land protection is fragmented into more regulations, for example, in the Act No. 364/2004 Coll. on waters (water act), Act No. 326/2005 Coll. on forests, Act No. 24/2006 Coll. on environmental impact assessment, etc.

Agricultural land protection is regulated by Act No. 220/2004 Coll., on the conservation and use of agricultural land and amending the Act No. 245/2003 Coll. on integrated pollution prevention and control and amending certain acts as amended. In terms of Section 1 of the Act, subject of the Act is legislative regulation of:

- protection of qualities and functions of agricultural land and ensurance of its sustainable management and agricultural exploitation,

- protection of the environmental functions of agricultural land, which are: biomass production, filtration, neutralization, and transformation of substances in nature, maintenance of the environmental and genetic potential of living organisms in nature,

- protection of agricultural land area against unauthor- ized occupation for non-agricultural use,

- procedures used when changing land type and procedures used when withdrawing agricultural land for nonagricultural purposes,

- penalties for breach of the obligations established by the Act.

Part II of the Act (Section 3-8 of the Act) lays down the principles of the sustainable agricultural land use and agricultural land management and land protection. Within the framework of the agricultural land care, the subjects mentioned are obliged to (Section 3 of the Act):

a) implement agro-technical measures aimed at the protection and preservation of the qualitative features and functions of the agricultural land and the protection against damage and degradation,

b) prevent the occurrence and spread of weeds on uncultivated lands,

c) ensure that the agricultural land is used in the way that does not threaten the ecological stability of the area and maintains the functional interrelatedness of the natural processes in the landscape,

d) organize and harmonize the agricultural land type with its data registered in the Cadastre.

Thus part II of the Act adjusts the most important environmental risks emerging in the agricultural land (degradation, erosion, compaction and protection against hazardous substances) and the maintenance of soil organic materials. The agricultural land care is left solely as an obligation of the owner, tenant or manager of agricultural land. Although the National Agricultural and Food Centre - Soil Science and Conservation Research Institute such serving representing a soil service can monitor and propose appropriate measures to mitigate or eliminate the unsatisfactory state, the implementation of the agro-technical measures itself, including financial costs, is left to the entities mentioned above. The Annexes to the Act quantify the limits for soil erosion, compaction and values of organic matter, and hazardous substances in soil. On the other hand, it is questionable whether specifying the limits is effective enough and sufficient for the maintenance of the good quality of agricultural land with a character determined by the nature of the land management practice during the socialist regime when several negative procedures were applied in order to increase the yield from land (crop management in large areas, the removal of the limits, windbreaks, etc.). Nevertheless, after 1990, the management of large areas continues in order to perform single crop cultivation to a certain extent, since the vast majority of agricultural land is used by cooperatives (39\%) and companies, especially limited liability companies and public limited companies (41\%) with the average land area of 1,267.26 ha in cooperatives, 456.77 ha in limited liability companies and 1,098.01 ha in public limited companies ${ }^{(9)}$. Based on the data mentioned above, the legislation on environmental risks and the legislation on breaches and other administrative offences following it (part VI of the Act) lacks a conceptual formula-

(9) Farm Structure Census 2010 
tion of obligations with connection to the historic character of agriculture in Slovakia and specification of the extent of the breach of the obligations of the owner, tenant or manager when caring for the environment.

The key part of the Act is part IV referring to the protection of agricultural land related to non-agricultural use. This part of the Act had been amended in order to limit the decrease in the amount of agricultural land several times. The basic principle in the protection of the agricultural land area is defined by Section 12 Paragraph 1 of the Act, which states that the agricultural land can be used for construction purposes and other non-agricultural purposes only when necessary and in legitimate amount. The basis used to indicate changes in the agricultural land type in the Cadastre are a final decision, binding opinion or an opinion of an agricultural land protection authority and a geometric plan, if the subject of the amendment is a part of the land registered in the Cadastre. In the procedures amending the agricultural land type, the agricultural land protection authority is obliged to ensure the protection of

a) agricultural land of the highest quality in the cadastral area according to the code of the bonited soil-ecological units provided in a separate regulation and b) vineyards.

The Act also introduced levies on withdrawal of agricultural land for the construction and other non-agricultural purposes through the institute of levies on withdrawal of agricultural land representing a systematic economic instrument for the protection of agricultural land of the highest quality.

Establishing the levies on withdrawal results in achieving three objectives beneficial for the whole society:

- protection and stabilization of the Slovak agricultural land area of the highest quality,

- guidance and, in a certain way, forcing construction investors to decrease the financial costs via directing at Slovak sites outside of the Bratislava and Trnava regions and orienting at soil of lower quality (BSEU in the $5^{\text {th }}$ to 9th group), sites less important in terms of the agricultural primary production and offering lower levies, and, based on the same economic interest, to limit their land requirements on the extent of withdrawal necessarily needed as well

- ensurance of the financial means for the operation of certain provisions of the Act, mainly activities related to the organization of agricultural land data in the Cadastre, including the true state of the terrain, the identification of the risk areas of the agricultural landscape and funding the remediation of the contaminated and otherwise devalued agricultural land sites, the establishment of an information system on lands.

Pillar II Integration - Inclusion of Soil Protection into Policies Elaborated and Implemented on Both Domestic and EU Levels

As far as the integration of environmental aspects into the protection of agricultural land is concerned, subsidy policy of the EU's Common Agricultural Policy played an important role, because it made the full amount of direct payments (sin- gle area payment) subject to by meeting the requirements of the cross-compliance. Valid Regulation of the European Parliament and the Council (EU) No. 1307/2013 laying down the rules for direct payments to farmers under support schemes within the framework of the Common Agricultural Policy and repealing Council Regulation (EC) No. 637/2008 and Council Regulation (EC) No. 73/2009 is specified by the Government Regulation No. 488/2010 Coll., on the conditions for granting support in the form of direct payments to agriculture, as amended. Section 7 of the Regulation specifies the conditions for granting direct payments in the form of the single area payment liable to meeting the minimum requirements which should prevent the environmental risks in agricultural land. The requirements are:

1. good agricultural and environmental conditions referred to in Annex No. 2 (the applicant for single area payment must meet the requirements related to the area of soil erosion, maintain the level of organic components of soil, soil structure, ensure the minimum maintenance level and prevent the deterioration of habitats and protect surface and ground waters against pollution)

2. management requirements determined in Annex No. 3 , including coefficients for the calculation of the amount of produced nitrogen specified in Annex No. 4 (the soil protection is referred to specifically in the 3rd area - environmental and, mainly, soil protection when using of sewage sludges and the 4th area - protection of waters against pollution caused by nitrates from agricultural sources

If the applicant for the single area payment did not meet the requirements set by the regulation, the payment would be reduced or completely cancelled. In that case, the supervisory body is Agricultural Paying Agency, or organizations empowered by the agency (Central and testing Institute in Agricultural, State Veterinary and Food Administration of the Slovak Republic), which control compliance with the requirements on the cross-compliance, however, only in entities applying for the single area payment. In terms of the integration of EU requirements on the area of soil protection into policies implemented at the national level, interconnection of the crosscompliance requirements on the quantitative conditions laid down in Act No. 220/2004 Coll. could be secured as it would unify the standards for the payees of the single area payment and for those, who are not receivers of the payment.

In terms of the support of the environmental aspects of the soil protection, Axis 2 of the Rural Development Programme plays an important role since the programme focuses on environment and landscape improvement; in the area of soil protection, especially agri-environmental measures are important. The aim of the agri-environmental measures is to implement agricultural production practice compatible with the protection and improvement of environment, landscape and natural resources. The conditions for granting the aid in this area are specified in Section 35 of the Government Regulation No. 499/2008 Coll. on the conditions for granting aid under the Rural Development Programme, as amended. Agri-environmental measures include the following submeasures:

- basic aid in arable land and permanent grassland; 
- integrated production in viticulture, fruit and vegetable sectors;

- organic farming on arable land, in cultivation of vegetables, medicinal, spice and aromatic plants, in vineyards, orchards, and on permanent grassland;

- protection from erosion through stabilizing crop rotation and establishment of a parcel of an acceptable size on arable land, protection in vineyards, orchards;

- grassing of arable land;

- protection of selected habitats and grasslands;

- protection of habitats of selected bird species;

- breeding and maintaning of endangered animal species.

The support of the agri-environmental measures has its meaning, because the applicants voluntarily commit to implement an environmental obligation laying beyond the cross-compliance requirements. Moreover, the financial aspect in the form of subsidies plays a significantly motivating role for the farmers ${ }^{(10)}$. The support of the agri-environmental measures will continue in the new programming period $2014-2020^{(11)}$.

Pillar III Filling the Known Gaps in Knowledge in Some Areas of Soil Protection through the Research Supported by the $\mathrm{EU}$

In terms of the research activities aimed at the protection, number of projects have been approved. Their aim is to improve knowledge in the area of soil protection, such as in the case of the projects of the National Agricultural and Food Centre - Soil Science and Conservation Research Institute (available at: http://www.vupop.sk/projekty_eu.php). An important role is played by the Slovak University of Agriculture in Nitra as well (e.g., Jean Monnet Centre of Excellence Land Policy - Pathway towards Sustainable Europe, available at: http://www.fesrr.uniag.sk/sk/centrum-excelentnosti/).

\section{Pillar IV Raising Public Awareness of the Need for Soil} Protection

Public awareness of soil protection is not so high. In most cases, the soil protection remains in professional circles. Nevertheless, a larger amount of information on soil quality is available, mainly at websites of state institutions in Slovakia.

\section{Summary}

Nowadays, land protection is a topical and much-debated issue in the European Union. The aim of this paper was therefore to analyze and evaluate the legislation regulation

(10) The results of the research in the area of the motivation of the farmers in organic farming was published in the paper of Palšová, L. [et al.]. The support of implementation of organic farming in the Slovak Republic in the context of sustainable development. ilustr.In: Procedia - Social and Behavioral Sciences. ISSN 1877-0428. Vol. 110, (2014), p. 520-529.

(11) Only a draft strategy paper on Rural Development Programme of the Slovak Republic for the programming period 2014-2020 from 29.04.2014 had been published until the publication date of the paper . [cit. 2014-05-16] Available at: http://www.mpsr.sk/ index.php?navID $=1$ \& $\mathrm{id}=8446$ of the protection of agricultural land in the context of the implementation of the thematic strategy for soil protection COM (2006) 231 final in Slovak conditions. The paper used secondary information sources and the methods of selection, analysis, induction, deduction scientific abstraction. The paper also observed the Thematic Strategy for Soil Protection (including agricultural land) establishing four pillars necessary for soil protection in Europe. One of the pillars of the strategy is a Proposal for a Framework Directive for the Protection of Soil, which is, however, not accepted by all the Member States due to non-compliance with the principles of subsidiarity, high costs, administrative burdening and overlapping of the European directive with national legislation of the Member States (Germany, France, Great Britain, Austria and the Netherlands). Despite the above mentioned discrepancy, a number of legal acts that have an impact on the improvement of the soil quality have been adopted in Europe.

Due to the analysis of the Thematic Strategy and its implementation in Slovak conditions, it can be stated that the Act No. 220/2004 Coll., on the conservation and use of agricultural land and amending Act No. 245/2003 Coll. on integrated prevention and control of environment pollution and amending certain laws, as amended, provides the basic framework for the care of the agricultural land protection. On the other hand, the Act can be reproached for lacking a certain level of conceptual approach and not taking into account historic conditionality related to the establishment of the responsibilities of the owner, tenant or manager. It would be more optimal if the Act oriented the responsibilities of the owner, tenant or manager towards the improvement of the agricultural land protection (establishment of green spaces, crop rotation applied on smaller areas, replanting windbreaks, etc.) Those obligations cover cross-compliance measures and requirements of the agri-environmental measures to a certain extent. However, they do so only when referring to the target group - applicants for the single area payment, or applicants for agri-environment measures support. In terms of raising awareness of the state of land, it would be suitable to open the public discourse on the importance of land and the need for its protection for current and future generations more often.

\section{References}

1. European Commission. 2012. Report from the Commission to the European Parliament, the Council, the European Economic and Social Committee and the Committee of the Regions. The implementation of the Soil Thematic Strategy and ongoing activities. COM (2012) 46 final.

2. Commission of the European communities. 2006. Proposal for a Directive of the European Parliament and of the Council establishing a framework for the protection of soil and amending and supplementing Directive 2004/35/EC. COM (2006) 232 final. 2006/0086 (COD).

3. Commission of the European communities. 2006. Communication from the Commission to the Council, the European Parliament, the European Economic and Social Committee and the Committee of the Regions. Thematic Strategy for Soil Protection. COM (2006) 232 final.

4. POTOČNIK J. in EAOsite editor. 2014. Soil directive appears 
doomed. [cit. 2014-05-14]. Available at: http://eaonsite.com/ index.php?option=com_k2\&view=item\&id=16589: soil-directive-appears-doomed\&Itemid $=675$.

5. RANKIN, J. in European Voice. 2010. Member states dig deep to stop soil directive. [cit. 2014-05-15]. Available at: http://www. europeanvoice.com/article/imported/member-states-dig-deepto-stop-soil-directive/67043.aspx.

6. Statistical Office of the Slovak Republic. 2012. Farm Structure Census 2010. Comprehensive results. ISBN 978808121163-8. [cit. 2014-05-14] Available at: http://www.fao.org/fileadmin/ templates/ess/ess_test_folder/World_Census_Agriculture/ Country_info_2010/Reports/Reports_4/SVK_ENG_SVK_ REP_2010.pdf.

7. Geodesy, Cartography and Cadastre Authority of the Slovak Republic. 2014. Statistical Yearbook on Soil Fund according to the data of the Cadastre from 1.1.2014. Bratislava: ÚGKK SR. ISBN 9788085672985. [cit. 2014-05-14] Available at: http://www. skgeodesy.sk/files/slovensky/ugkk/kataster-nehnutelnosti/ sumarne-udaje-katastra-podnom-fonde/statisticka-rocenka2013.pdf.

8. Act No. 220/2004 Coll., on the conservation and use of agricul- tural land, amending the Act No. 245/2003 Coll. on integrated pollution prevention and control, amending and supplementing of certain acts, as amended.

9. Government Regulation No. 488/2010 Coll., on the conditions for granting support in the form of direct payments to agriculture, as amended.

10. Government Regulation No. 499/2008 Coll. on the conditions for granting aid under the Rural Development Programme, as amended.

\section{Contact address/ Kontaktná adresa}

\section{JUDr. Lucia Palšová, PhD.}

Department of Law,

Faculty of European Studies and Regional Development

Slovak University of agriculture in Nitra

Trieda Andreja Hlinku 2, 94976 Nitra

Tel: 037/6415079

E-mail: lucia.palsova@uniag.sk 